\title{
The Analysis of the Origin, Resurgence and Future Nationalism Development of United States
}

\author{
Chenhe Ding ${ }^{1, \dagger}$ Luding $\mathrm{Hu}^{2, \dagger}$ Sibo Zhao ${ }^{3, *}, \dagger$ \\ ${ }^{1}$ Hemdemhall Country Day School, Connecticut, USA \\ ${ }^{2}$ Kang Chiao International School, Suzhou, Jiangsu, China \\ ${ }^{3}$ Hongwen Internationa School, Chengdu, Sichuan, China \\ *Corresponding author email:guanghua.ren@gecacademy.cn \\ These authors contributed equally.
}

\begin{abstract}
The global military and development capacities of the U. S. are among the world's top nowadays. Under the impact of the COVID-19 virus and multilateralism, right-wingers, conservatives and anti-globalists are becoming the world's emerging issues in the future. On this basis, we explore the concept of nationalism in U. S. context. Specifically, the historical origins of nationalism and modern developments to uncover the nationalist ideology hidden under the "patriotism" of the United States are analysed. The objective of our study is to dig out the American history surrounding nationalism and to find out the causes for this trend. We refer to the articles of social scientists, historians and the U.S. Constitution, focusing on books and authoritative papers and journals, and analyse their theories and examples of nationalism in detail. In addition, we also retrieve some recent news reports to uncover the recent foreign policy of the U. S. According to the analysis, American nationalism has been showing a continuous increase ever since its development, which have great danger for conflicts in the future. Our work covers the danger of having excessive nationalism in general.
\end{abstract}

Keywords: Hegemonism, Liberalism, Nationalism, U.S., Patriotism.

\section{INTRODUCTION}

Contemporarily, the United States is the only superpower in the world, and its global military strike and deployment capabilities are the world's top. The cultural export of the United States is also quite successful. The Statue of Liberty has become a popular attraction in the world. People from all over the world come to admire the statue on this small island, expressing their recognition of Americanism and ideology. However, with freedom and democracy as its core values, even the United States cannot conceal its own nationalism. In particular, as the United States has entered the 21st century, under the pressure of the rise of terrorism and multilateralism, the United States' own nationalism and patriotism have become clear. On the border, the U.S. constructed border wall to block immigrants from Central and South America. In the Middle East, the U.S. launched the Afghan war and caused killings on the lands of other countries. As for Asia, in order to contain the rise of its rival, China, it set up the diplomatic barriers of the first island chain and the second island chain. American sociologist Chalmers Johnson accused the United States' diplomacy as a manifestation of narrow nationalism. According to Johnson, American officials and the media talk a great deal about "rogue states" like Iraq and North Korea, however, it is not certain yet whether the United States has itself become a rogue superpower [1]. While preaching that the United States is inclusive and diverse, it also beats regimes that may threaten its hegemony with incomparably narrow isolationism and nationalism.

There are plenty of recent studies done in this field. The term racism is used to describe the hostile or negative feelings of one ethnic group or "people" toward another and the actions resulting from such attitudes [2]. Recent studies have indicated that there has been a growing nationalism in USA ever since $9 / 11$, which is especially targeting against the people in middle east [3]. There are many studies believe that pop cultures after $9 / 11$ have helped developing domestic nationalism [4]. This nationalistic idea of America is the superior to those of the middle eastern countries, moreover, can also be seen as the continuation of the orientalism that Edward Said pointed in his famous book: Orientalism. In this book, he 
described the phenomenon that people in the west depict people in the east into ways that are not actually true in order to justify the imperialism of the west [5].

Most of the existing studies done in this field mostly reach a common conclusion that nationalism in USA had been raising constantly. The reason for the rise varies from recent terrorist attack to the justification of imperialism. The subject of our research is the nationalist sentiments of American citizens. Under the impact of the COVID-19 virus and multilateralism, right-wingers, conservatives and anti-globalists are becoming the world's talkers in the future. We will analyse and criticize American nationalism in this paper. We combine historical backgrounds, e.g., the large-scale white supremacy triggered by the social Darwinian thought mentioned above, to the American xenophobia and modern nationalism of Trump who built the border wall. As we all know, the word patriotism is a word widely used in the United States to express its own patriotic thoughts. We analysed the historical origins of nationalism and modern developments to uncover the nationalist ideology hidden under the "patriotism" of the United States.

This paper will be divided into three sections. The first session would provide a review on theories regarding nationalism and applying them on both a cultural and political perspective. The second section would discuss how American nationalism was formed and developed. The final section would provide an analysis of future development of nationalism. We would extend from existing theories and attempt to provide future outlooks of nationalism via different perspectives.

\section{CULTURAL AND POLITICAL PERSPECTIVE OF NATIONALISM}

The nationalism of U.S. is, in its essence, the best example of what Anderson would call "imagined political community" [6]. Its historical heritage is rather limited, while liberal ideologies and state identities has taken the role of it. US nationalism also has a closer relationship with patriotism, as both concepts are vaguely utilized to represent both. In his investigation on the paradoxes of nationalism, Pei state "the psychological and behavioral manifestations of nationalism and patriotism are indistinguishable, as is the impact of such sentiments on policy" [7].

\subsection{Two traditions of nationalism}

Moreover, as the American nation is often vaguely defined, nationalism itself is also interpretated in different ways. Two nationalist interpretations have become popular. The Wilsonian tradition focuses on spreading nationalism and ideological ideals internationally. The Jacksonian tradition believes that America is better off when keeping its way of life to itself
[8]. Both traditions coexist in the modern society and are often in conflict with each other in political fields. The Wilsonian tradition, derived from President Woodrow Wilson, who expanded American influence abroad after WWI, focuses on spreading freedom and democratic ideas and establishing global leadership. On the opposite of the spectrum are Jacksonians, believing that the nation should not influence foreign forces unless it is for the benefit of the US directly. It reviews past US conflicts abroad and regards many of them as unnecessary sacrifices, and tries to pull the country away from international cooperation, as they believe that it deals more harm than benefit. A good representative of Jacksonian tradition would be President Trump. His "American First" policy has pulled U, S, out of international treaties (e.g., WHO), and cancelled foreign military aids.

Kazin categorizes Jackson's policies as “toughness, whiteness and maleness" [8]. Trump's Jacksonian nationalism is exclusive, rejecting immigration and foreign influences, and defends a traditional community life. Such strategies of dividing out groups based on nationality and promotion of a mostly white-based lifestyle leads to xenophobia and racism, which are often practiced all under the banner of patriotism [9]. According to Pulido's research on the President's racial tweets, while the black and native Americans received relatively little racism rhetoric, Trump focused more on Latinx, Muslims and Asians. Besides, rather than attacking countries, he more often targeted against ethnic groups and nations. Indeed, Trump generalizes nationalism fear into racism hatred [10].

Another important characteristic of Jacksonian nationalism is a hostile stand against costal city elites, which also a stance Trump firmly takes. As Trump uses populist nationalism as his propaganda strategy, many with opposing view on Jacksonian nationalism had lost faith in nationalism as a whole. While $55 \%$ of republicans say that they are proud of their country most of the time, only $17 \%$ of left wing agrees [11]. Many also identified Trump as why they are "ashamed to be American". Democrats even associate the word Patriots with Trump supporters. On the other hand, most Republicans believe that patriotism has a positive meaning to it. By practicing Jacksonian tradition, the concept of nation is narrowed. Those that are of different race, living different lifestyles or believing different ideologies are considered as the outgroup.

\subsection{Nationalism as a force of unity}

Similar to all nationalism, American nationalism is limited. However, the ideology-based structure grants it power to not only divide, but also unite people. Nationalism is able to give people a superordinate goal to work toward. This goal will eliminate in-group biases, and grants people to unite to work toward a common 
enemy-the outgroup, or in nationalism's case, foreigners. Besides, as more and more recent migrants of different ethnicities identify themselves all as "American", the national identity have certainly expanded [12].

US nationalism is fluid and ambiguous in its definition. This made nationalism and its political extension-patriotism-open for interpretation and explanations. In the present-day US, the revival of conservative ethnonationalism-Jacksonianism, along with globalist Wilsonianism, had bring this debate of "what is America" into an international context of what it should become in a global stage. It also affects civil rights movement, especially to the new wave of migrants from Latin America and Asia.

\section{HISTORICAL CAUSES OF NATIONALISM}

\subsection{Puritanism}

American nationalism is related to the formation of the American nation. In retrospect, Americans do not come from a particular race (Anglo-Saxon, Germanic, Viking), nor do they have the same culture and religion. As a result, political values have become the mainstay of American nationalism. According to Anthony D. Smith's statement, though the United States was built on the cultural base of a successive waves of immigration have turned it into a truly poly-ethnic and diverse nation, yet formed with a common language, identical laws, shared political symbols and the tradition of saluting the flag, celebrating public holidays and the cult of the US Constitution [13]. In 1620, in order to escape religious persecution in the British mainland, the priest Bryster took the "Mayflower" across the Atlantic and led a group of Puritans to the United States. Later, the descendants of these colonists took root in the United States and developed feelings for the land they lived in.

In the 18th century, the American founders succeeded in turning the biblical millennial doctrine of the Puritans into a secular millennial doctrine. "The millennialism of Christianity was transformed and became the basis of American nationalism and American exceptionalism" [14]. In other words, the people of North America have always believed that their colonization of the entire North American continent is a "divine-inspired" enterprise. Besides, it is the effort of God's chosen people to create a new world in God's promised land. This built "City upon a hill" will become a model for other countries and a "beacon" to illuminate the world. This awareness has made the people of the North American continent have a strong sense of mission of "destiny determined by heaven" from the very beginning. Through the story of the founding of the United States, we can easily find that the values that permeate the American people, e.g., freedom, democracy, and equality, are the mottos of the
Puritans, that is, the ideas brought by the first group of colonists who came to the United States. This is also the source of this special nationalist ideology in the United States, not just based on a single nation.

\subsection{Liberalism}

In the middle of the 18th century, with the outbreak of the Seven Years' War between Britain and France and the victory in exchange for the great price of Britain, the United States, as a British colony, suffered heavy taxes from the sovereign state. In order to resist the ravages of European imperialism in the United States, the United States has successively erupted against British colonization, e.g., the Boston Tea Party and the first Continental Congress. The United States was colonized by those who escaped from the feudal and religious oppression of the old world. In this sense, if there is something as old as the national tradition itself, then the prominent point of American society in Western history is that there are no such oppressions, or in a broad sense, because the reaction to those oppressions is Liberal, i.e., American society is a liberal society [15]. On April 19, 1775, with the first shot of Lexington, the American War of Independence officially broke out. On July 4, 1776, the United States officially became independent after experiencing an arduous war of independence. The final document, engrossed by Jacob Shalesa's taken up on Monday, September 17, at the convention's final session [16]. These two documents have therefore become the foundation of the founding of the United States. They marked the birth of a new country where independence, democracy and freedom merge. Born unyielding, how can the US easily bow to the forces of other countries? The history of the founding of the United States is destined for its people to be strong, self-reliant, unanimous to the outside world, and extremely proud of their country. As a colony freed from imperialist rule, the United States was born anti-European powers, and the United States has become a place of freedom that the suffering people of countless colonies yearn for.

\section{FUTURE DEVELOPMENT OF AMERICA NATIONALISM}

There has always been tension between the west and the east ever since the west started to demonize the east to justify their imperialistic action [5]. This aggression towards the middle east has been severely worsen in recent decades as discussed earlier. However, the question lies ahead is what will this increased hostility and American nationalism take us in the future. There are two sides for this issue, in some perspective the relationship will improve, but others indicates that the situation would worsen. It is obvious that the future relationship between America and middle east, is not going to improve in the short run. Ever since the recent events from 9/11 to assassination of Soleimani, the 
tensions have been raising between those two countries. It is not hard to say that tensions will not go away in short term. After the assassination of Soleimani, there has been a lot of raising sentiment within Iraq against America. This has also been responded by increasing nationalism within America. Immediate after the assassination, there are signs of escalating tensions between America and Iraq. Those action varied from Iraqi citizen burning American flag to Iraqi military firing rockets into Bagdad [17]. In USA's side, assassination of Soleimani has been proven to be invaluable for Trump's administration office [18]. It helped the president to defend against a potential impeachment, gain support of public opinion and to rally "round-the -flag" effect. Nevertheless, internationally speaking is a different story., where action taken by the Iraqi military after the assassination is a small, yet representative. The air strikes carried out by Iraqi military signals Iraqi's discontent towards American aggression. This gives us an insight of what can be expected for the future. Iraq in no way will be happy at American's action, i.e., they will keep sending out military signals they are not going to keep tolerating American's aggression. This, in long run, has high possibility of turning into something more serious.

There are also severe expansions of domestic American nationalism under Trump administration. For example, Trump encouraged The Proud Boys (a far right, neo-fascist, white supremacy group) to storm the capital mountain [19]. This kind of action is the exact result from American nationalism growing among radical groups.

This have negative effect on both domestic level and international level clearly. Fortunately, one could argue that the situation is going to, or even already have been improved. This is because that they argue that America's nationalism generated from their participation in middle east has shifted from trying to get oil and establish oil monopoly in the international market to being attacked by terrorism. This means that America nationalism has been weaken considerably since America stop trying to get establish oil monopoly and justify their action using nationalism [20]. Nevertheless, even with the nationalism weakened, it still could cause serious consequence as other countries might get hurt by America nationalism and look for revenge. Recently, there has been an ongoing discussion on the possibility on "The Third World War", especially after the assassination of Soleimani. Many believed that the assassination looked a lot like when Franz Ferdinand was assassinated and would lead to similar consequences. Moreover, with the tension between America and China, it seems like two major powers in the world are on the brink of war. Although the possibility of immediate total war is very low, there is no denial that we have come very close to what could be another tragic event for humanity.

Overall, there is no guarantee for our future. The situation could get better with America showing less intention to involve in middle east oil industry. Whereas it could get a lot worse if America extreme nationalism got out of control without proper government intervention. This might end up with America upsetting other countries.

\section{CONCLUSION}

The American President Theodore Roosevelt said in 1899: "Our entire national history is a history of expansion." Throughout the history of the United States, nationalism sprouted from Puritanism. The resulting individualism, after the religious colour has faded, still affects generations of young people. This kind of thinking has expanded to the entire democratic world and has penetrated into the minds of countless people.

The United States has not only completed its territorial expansion, but American ideology has spread to the wider world. Democracy and freedom, these two words became ideas that came out of the United States. Countless people took to the streets, launched strikes, and fought for their freedom. In the United States, the government has repeatedly used the reason of "helping dictatorships to build a democratic society" to cover up their attempts to deploy military forces around the world. Meanwhile, it invigorated U.S. citizens at home and fostered their sense of superiority over the American system.

In summary, we examined US nationalism from political, historical and futuristic perspectives. US nationalism is a diverse idea composed of different interpretations to it. The two main influential traditions in modern day, Jacksonianism and Wilsonianism, take different approaches on defining American identity and attitudes on outer world. The different approaches on nationalism can also become force of dividing or unifying American societies, especially ethnic groups. The power of American nationalism is originated from its history. The foundation of Puritanism justified American nationalism on a religious basis. It created a mandate of the American nation. Liberalism provided basic philosophical and political foundations for nationalism, supporting the legitimacy of the independence and freedom of the American nation. As the country is becoming radicalized in both its foreign and domestic policies, US nationalism may not have a positive outlook. It may become a justification for invasion and irresponsible international actions. It will further limit the American national identity and divide the society.

Through these investigations and conclusions, it is apparently that the ideology with individual freedom rights as the core constitutes the main ideological foundation of American nationalism and hegemonism. The inevitable connection between them is the superiority of the people and their self-confidence as the world's number one power. Our work concerns everyone in the world. Since nationalism is such a powerful tool in 
the world with potential consequence of starting another world scale war. For this reason, our finding warns people that we should be constantly alarmed the expanding nationalism in America. Therefore, American nationalism, is posing more threat to humanity than ever.

\section{REFERENCES}

[1] C. Johnson (2000). Blowback: The Costs and Consequences of American Empire, New York: Henry Holt. Page 216.

[2] G. M. Fredrickson, (2015). Racism. In Racism. Princeton University Press.

[3] Q. Li, M. B. Brewer, (2004). What does it mean to be an American? Patriotism, nationalism, and American identity after 9/11. Political Psychology, 25(5), 727-739.

[4] L. R. Foster, (2006). Music, publics, and protest: the cultivation of democratic nationalism in post-9/11 America (Doctoral dissertation).

[5] E. Said, (2020). Orientalism (pp. 423-426). Routledge.

[6] B. Anderson, (1991). Imagined communities. Verso.

[7] M. Pei, (2003). The Paradoxes of American Nationalism. Foreign Policy, (136), 30-37.

[8] A. Lieven, (2016). Clinton and Trump: Two Faces of American Nationalism. Survival, 58(5), 7-22.

[9] H. Restad, (2020). What makes America great? Donald Trump, national identity, and U.S. foreign policy. Global Affairs, 6(1), 21-36.

[10] L. Pulido, T. Bruno, C. Faiver-Serna, C. Galentine, (2019). Environmental Deregulation, Spectacular Racism, and White Nationalism in the Trump Era. Annals Of The American Association Of Geographers, 109(2), 520-532.

[11] L. Silver, M. Fagan, A. Connaughton,M. Mordecai, (2021). National Pride and Shame in U.S., UK, France and Germany. Pew Research Center's Global Attitudes Project. Retrieved 17 June 2021, from https://www.pewresearch.org/global/2021/05/05/5national-pride-and-shame/.

[12] J. Transue, (2007). Identity Salience, Identity Acceptance, and Racial Policy Attitudes: American National Identity as a Uniting Force. American Journal Of Political Science, 51(1), 78-91. https://doi.org/10.1111/j.1540-5907.2007.00238.x

[13] A. D. Smith, (2014). 'Ethnic' and 'Civic' Nationalisms. In Nationalism: theory, ideology, history. Polity Press.
[14] Y. Ding (2006). Critique of the US: Paradox of the Expansion of Liberal Empire. Beijing: Peking University Press.

[15] L. Hartz,T. Wicker, (1991). The liberal tradition in America: An interpretation of American political thought since the Revolution. Harcourt Brace Jovanovich.

[16] J. R. Vile, (2005). The Constitutional Convention of 1787: a comprehensive encyclopedia of America's founding. ABC-CLIO.

[17] Aljazeera, (4 Jan 2020). Aftermath of Soleimani killing in US raid: All the latest updates. Retrieved from https://www.aljazeera.com/news/2020/1/4/aftermat h-of-soleimani-killing-in-us-raid-all-the-latestupdates

[18] A. B. Binkaya, (2020). Causes and effects of the assassination of qasem soleimani: a political perspective. The Copernicus Journal of Political Studies, (1), 159-166.

[19] L. Leatherby, A. Ray, A. Singhvi, C. Triebert, D. Watkins,H. Willi. (Jan. 12, 2021). How a Presidential Rally Turned Into a Capitol Rampage. Retrieved from https://www.nytimes.com/interactive/2021/01/12/u s/capitol-mob-timeline.html

[20] T. C. Jones, (2012). America, oil, and war in the Middle East. The Journal of American History, 99(1), 208-218. 